Original Paper

\title{
Meningkatkan Kemapuan Guru Menerapkan Kurikulum Berbasis Komptensi Di Pondok Pesantren Al-Aziziah Gunungsari Lombok Barat
}

\author{
M. Yamin ${ }^{1 *}$, Jamaluddin', Abdul Syukur ${ }^{1}$, Khairuddin' ${ }^{1}$ \\ ${ }^{1}$ Program Studi Pendidikan Biologi Fakultas Keguruan dan Ilmu Pendidikan, Universitas Mataram
}

*Corresponding Author:

M. Yamin, Program Studi

Pendidikan Biologi Fakultas

Keguruan dan Ilmu Pendidikan,

Universitas Mataram, Indonesia;

Email:

muhammadyamin.fkip@gmail.com

\begin{abstract}
Abstrak: Kegiatan ini bertujuan untuk meningkatkan kemampuan guru dalam menerapkan KBK dalam pembelajaran sains di Pondok Pesantren yang berlokasi di kecamatan Gunung sari. Pendekatan yang digunakan dalam kegiatan penyuluhan ini adalah pendekatan androgogi yaitu pendekatan pembelajaran untuk orang dewasa. Pendekatan ini menekankan pada peran aktif peserta penyuluhan dalam melakukan kajian materi dan kegiatan latihan penyusunan silabus dan program pengajaran berdasarkan KBK. Kegiatan ini dilakukan dalam bentuk presentasi, diskusi, dan kerja kelompok. Subyek yang dilibatkan dalam kegiatan penyuluhan ini adalah para guru bidang studi MTs dan MA di Podok pesantren Al Aziziah. Pelaksanaan kegiatan ini mampu meningkatkan kemampuan guru-guru MTs/MA di Pondok pesantren Al Aziziah untuk menerapkan KBK dalam pembelajaran. Dengan demikian kualitas pembelajaran di lingkungan pondok pesantren dapat ditingkatkan secara bertahap dan berkelanjutan
\end{abstract}

Kata Kunci: Kemampuan guru; Kurikulum; KBK

\section{Pendahuluan}

Pemerintah telah menetapkan dua kebijakan pokok melalui Gerakan Peningkatan Mutu Pendidikan untuk meningkatkan mutu pendidikan yang dicanangkan pada tanggal 2 Mei tahun 2002. Gerakan tersebut di harapkan dapat mengembangkan kecakapan peserta didik sesuai dengan kebutuhan dalam persepektif global. Dua kebijakan pokok dimaksud yaitu pertama, berkaitan dengan efisiensi pengelolaan pendidikan, Pemerintah telah menerapkan Majemen Berbasis Sekolah (MBS). Kedua, untuk lebih memacu percepatan peningkatan mutu pendidikan pemerintah mulai tahun 2004 telah memberlakukan kurikulum berbasis kompetensi (KBK).

Dalam undang-undang no. 22 tahun 1999 dinyatakan bahwa otonomi pendidikan adalah pengalihan atau seluruh kewenangan di bidang pendidikan yang selama ini dilakukan oleh pemerintah pusat kepada pemerintah daerah. Adapun ototnomi pendidikan daerah merupakan kewenangan daerah otonom untuk mengatur dan mengurus kepentingan masyarakat. Otonomi pendidikan akan memberikan peran yang luas untuk memikirkan dan meningkatkan kualitas pendidikan. Dengan kata lain otonomi pendidikan di daerah akan mengurangi kewenangan pemerintah pusat dalam mengintervensi kewenangankewenangan daerah otonom (Muhtar \& Suparto, 2003).

Daerah hendaknya mampu menetapkan standar nilai dalam upaya meningkatkan mutu pendidikan di daerahnya. Disini daerah mempunyai peluang untuk melakukan berbagai misalnya: mendesain silabus yang sesuai dengan kebutuhannya, meningkatkan mutu pembelajaran di kelas, dan mendesain sistem ujian sendiri, sehingga tidak terjebak dalam segala sesuatu yang bersifat seragam di seluruh provinsi (Depdiknas 2002).

Kurikulum berbasis kompetensi adalah kurikulum yang dirancang agar dapat memnghasilkan lulusan yang kompeten dalam arti memiliki pengetahuan, ketrampilan, sikap, dan nilai-nilai dasar yang direfleksikan dalam kebiasaan berfikir dan bertindak. Dalam perumusan kurikulum berbasis kompetensi pusat bertanggung 
jawab untuk menentukan standar kompetensi, kompetensi dasar, dan materi pokok, sedangkan daerah atau sekolah bertanggung jawab mengembangkan silabus (Mulyasa, 2004).

Pengembangan kurikulum berbasis kompetensi (KBK) memfokuskan pada kompetensi tertentu, berupa paduan pengetahuan, keterampilan dan sikap yang dapat didemonstrasikan oleh peserta didik sebagai wujud pemahaman terhadap konsep yang dipelajarinya. Penerapan kurikulum berbasis kompetensi memungkinkan para guru menilai hasil belajar peserta didik dalam proses pencapaian sasaran belajar yang mencerminkan penguasaan dan pemahaman terhadap apa yang dipelajarinya, oleh karena itu peserta didik perlu mengetahui kriteria penguasaan kompetensi yang akan dijadikan standar penilaian hasil belajar shingga siswa dapat mempersiapkan dirinya melalui penguasaan terhadap sejumlah kompetensi tertentu sebagai prasyarat untuk melanjutkan ke tingkat berikutnya.

Kompetensi yang dinyatakan adalah kompetensi lulusan, kompetensi standar, dan kompetensi dasar. Kompetensi lulusan adalah kompetensi yang harus dicapai ketika siswa tamat dari suatu jenjang pendidikan. Kompetensi standar/ bakuan kinerja yang harus dicapai ketika siswa menyelesaikan suatu mata pelajaran tertentu. Kompetensi dasar merupakan ukuran minimal/memadai yang ditetapkan kemampuan, ketrampilan, sikap, prilaku dasar dalam menguasai materi. Kompetensi dasar itu harus dikembangkan, dilatihkan, dan dialami siswa secara maju dan berkelanjutan seiring dengan perkembangannya untuk menjadi mahir berkinerja dalam memecahkan masalah (Yulaelawati, 2001)

Pondok pesantren merupakan bagian penting dari sistem pendidikan di NTB khususnya di pulau Lombok yang perlu mendapat perhatian Pemerintah daerah dalam kaitannya dengan penerapan KBK. Perhatian dimaksud dapat berupa bantuan untuk meningkatkan kemampuan guru-guru pondok pesantren, karena penerapan KBK dalam pembelajaran menuntut guru yang berkualitas dan profesional.

Penerapan KBK di lingkungan Pondok Pesantren menghadapi beberapa faktor yang menjadi masalah dan amat berpengaruh terhadap keterlaksanaan KBK. Masalah-masalah tersebut diantaranya pemahaman guru tentang KBK, kemampuan guru dalam mengembangkan silabus dan sistem penilaian, dan kemampuan guru dalam menerapkan KBK dalam pembelajaran.

Masalah-masalah tersebut merupakan masalah pokok yang harus diatasi, karena apapun bentuk kurikulum yang dikembangkan oleh pemerintah bila tidak didukung pelaksanaannya oleh kemampuan guru, pada akhirnya KBK tidak dapat dilaksanakan secara efektif. Hal ini akan semakin memperburuk kualitas pendidikan di daerah NTB.

Demikian pula dengan masalah yang dihadapi oleh pondok pesantren Al Aziziah Kecamatan Gunung sari Kabupaten Lombok Barat. Pondok pesantern tersebut sangat mengharapkan bantuan dosen FKIP Unram yang menguasai KBK untuk memberikan penyuluhan bagi guru-guru MTs dan MA tentang penerapan KBK dalam pembelajaran. Bantuan dimaksud sangat diperlukan karena para guru di pondok pesantern belum memiliki pemahaman dan kompetensi yang cukup untuk menerapkan KBK.

Untuk mengatasi masalah kurangnya pemahaman dan kemampuan guru tentang KBK perlu dilakukan melalui kegiatan penyuluhan untuk meningkatkan kemampuan guru dalam menerapkan KBK Penyuluhan dimaksud amat mendesak untuk dilakukan karena para guru MTs dan MA di pondok Pesantren tersebut belum memperoleh penataran atau pelatihan tentang KBK karena keterbatasan sumberdaya dan sumberdana yang dimiliki oleh pondok pesantren. Al Aziziah.

\section{Metode Pelaksanaan}

Pendekatan yang digunakan dalam kegiatan penyuluhan ini adalah pendekatan androgogi yaitu pendekatan pembelajaran untuk orang dewasa. Pendekatan ini menekankan pada peran aktif peserta penyuluhan dalam melakukan kajian materi dan kegiatan latihan penyusunan silabus dan program pengajaran berdasarkan KBK. Kegiatan ini dilakukan dalam bentuk presentasi, diskusi, dan kerja kelompok.

Subyek yang dilibatkan dalam kegiatan penyuluhan ini adalah para guru bidang studi MTs dan MA di Podok pesantren Al Aziziah. Para guru teersebut belum memahami dengan benar tentang konsep, prinsip dan penerapan KBK masingmasing mata pelajaran. Pemahaman guru-guru pondok pesantren tentang penerapan KBK amat 
penting karena mulai tahun ajaran 2004-2005 pemerintah telah mulai memberlakukan KBK 2004. Sementara itu para guru di pondok pesantren tersebut belum memiliki pemahaman dan kemampuan yang cukup untuk melaksanakan KBK dalam pembelajaran.

\section{Hasil dan Pembahasan}

Pengembangan kurikulum berbasis kompetensi (KBK) memfokuskan pada kompetensi tertentu, berupa paduan pengetahuan, keterampilan dan sikap yang dapat didemonstrasikan oleh peserta didik sebagai wujud pemahaman terhadap konsep yang dipelajarinya. Penerapan kurikulum berbasis kompetensi memungkinkan para guru menilai hasil belajar peserta didik dalam proses pencapaian sasaran belajar yang mencerminkan penguasaan dan pemahaman terhadap apa yang dipelajarinya, oleh karena itu peserta didik perlu mengetahui kriteria penguasaan kompetensi yang akan dijadikan standar penilaian hasil belajar shingga siswa dapat mempersiapkan dirinya melalui penguasaan terhadap sejumlah kompetensi tertentu sebagai prasyarat untuk melanjutkan ke tingkat berikutnya.

Kegiatan pengabdian yang dilakukan pada guru-guru MTs/MA di Pondok pesantren Al Aziziah telah menguntungkan bagi: 1) Guru, meningkatnya pemahaman dan ketrampilan guru dalam melaksakanan pembelajaran berdasarkan Kurikulum berbasis kompetensi. 2) Siswa, meningkatnya kemampuan guru akan berdampak pada kualitas pembelajaran, dengan demikian guru dapat mengembangkan kompetensi siswa sesuai dengan tuntutan KBK. 3) Pondok Pesantren, meningkatnya kemampuan guru tentang KBK akan berdampak pada meningkatnya kualitas pembelajaran, dengan demikian pondok pesantren akan dapat meningkatkan kualitas lulusannya. 4) FKIP Unram, penyuluhan ini merupakan salah bentuk kepedulian FKIP terhadap upaya peningkatan mutu pendidikan khususnya di pondok pesantren. Dengan dihasilkannya lulusan pondok pesanteren yang lebih berkualitas akan berdampak pada peningkatan calon mahasiswa yang berminat untuk menjadi guru.

Untuk mengetahui hasil dari kegiatan pengabdian ini diadakan evaluasi melalui diskusi dan tanya jawab baik pada penyampaian materei maupun di lapangan.

1. Diskusi. Kegiatan diskusi dilakukan dengan peserta penyuluhan. Dalam kegiatan ini peserta akan dibekali dengan konsep dan prinsip Kurikulum berbasis kompetensi.

2. Pembimbingan. Peserta akan dibimbing tentang penerapan KBK di MTs dan MA. Setiap mata sajian diberikan dengan cara pemaparan diskusi, simulasi dan diakhiri dengan latihan. Untuk itu strategi sajian, pengorganisasian peserta, alat bantu, porsi waktu yang digunakan dan penyajiannya telah dipersiapkan sebelumnya

Setelah guru-guru MTs dan MA yang bertugas di Pondok pesantren Al Aziziah. Peserta dimaksud terdiri atas 20 orang guru diberikan bimbingan tentang penerapan KBK. Untuk mengetahui keberhasilan kegiatan penyuluhan ini dilakukan kegiatan evaluasi proses dan evaluasi hasil. Evaluasi proses dilakukan selama kegiatan penyuluhan. Sedangkan evaluasi hasil didasarkan pada hasil kerja kelompok ddan individu dalam mengembangkan silabus dan program pembelajaran berbasis kompetensi. Tolok ukur keberhasilan kegiatan penyuluhan ini adalah bila guru-guru yang terlibat dalam kegiatan penyuluhan ini telah dapat menyusun silabus dan rencana pembelajaran berbasis kompetensi.

\section{Kesimpulan}

Pelaksanaan kegiatan ini mampu meningkatkan kemampuan guru-guru MTs/MA di Pondok pesantren Al Aziziah untuk menerapkan KBK dalam pembelajaran. Dengan demikian kualitas pembelajaran di lingkungan pondok pesantren dapat ditingkatkan secara bertahap dan berkelanjutan.

\section{Daftar Pustaka}

Depdiknas. 2002. Kebijakan Tekhnis dan Program Pengembangan Pendidikan Menengah Umum di Masa Depan. Dirjen Dikdasmen (Makalah tidak diterbitkan).

Muhtar \& Suparto, W. 2003. Manajemen Berbasis Sekolah. Jakarta: CV Fifamas 
Mulyasa, E. 2004. Kurikulum Berbasis Kompetensi, Konsep, Karakteristik, dan Implementasi. Bandung: PT Remaja Rosdakarya.

Yulaelawati, E. 2001. Kurikulum Berbasis Kompetensi dan Standar Nasional, Pusat Kurikulum Balikbang Departemen Pendidikan Nasional, (Makalah tidakm diterbitkan). 